\title{
CLINICS IN SPORTS MEDICINE
}

FORTHCOMING ISSUES

July 2017

Articular Cartilage

Eric McCarty, Editor

October 2017

The Female Athlete

Siobhan M. Statuta, Editor

January 2018

Controversies of the Anterolateral Complex of the Knee

Freddie H. Fu, Editor
RECENT ISSUES

January 2017

Controversies in ACL Reconstruction

Darren L. Johnson, Editor

October 2016

Return to Play Following

Musculoskeletal Injury

Brett D. Owens, Editor

July 2016

Hip Arthroscopy

F. Winston Gwathmey, Editor

\section{RELATED INTEREST}

Facial Plastic Surgery Clinics of North America, February 2017 (Vol. 25, Issue 1)

Facial Scar Management

David B. Hom, Editor

Available at: http://www.facialplastic.theclinics.com/

THE CLINICS ARE AVAILABLE ONLINE!

Access your subscription at:

www.theclinics.com 